\title{
Low Cost Production of Bacterial Cellulose from Food Processing Residues
}

\author{
Tadashi Takahashi, Junji Ichita, Yoji Kato ${ }^{1)}$ \\ Aomori Industrial Research Center, 4-11-6 Daini-tonyamachi, Aomori, 030-0113 Japan \\ Fax: 81-017-739-9613, e-mail: takahashi@aomori-tech.go.jp \\ ${ }^{1)}$ Hirosaki University, 1 Bunkyo-cho, Hirosaki, Aomori, 036-8560 Japan
}

\begin{abstract}
Apple pomace and soy pulp (okara) were discharged from food processing companies in Aomori Prefecture, and the additional value for utilization of these residues has been requested for the long time. It was known that the cellulose produced by some strains of bacteria, the cellulose was called Bacterial Cellulose $(\mathrm{BC})$. However, the costs of production were high, so the utilization of the $\mathrm{BC}$ cannot become widespread. In this study, we investigated the conditions to produce the $\mathrm{BC}$ at low-cost, and the following five experiments were carried out; 1) screening of $\mathrm{BC}$ producers, 2) production of the $\mathrm{BC}$ by using the commercial reagents at low-cost, 3) screening of the commercial crude cellulase suitable for apple pomace, 4) production of the $\mathrm{BC}$ by using the saccharified solutions of apple pomace, and 5) production of the $\mathrm{BC}$ by using the saccharified solutions of apple pomace and okara. As results, strains of Gluconacetobacter xylinus NBRC-16682 and NBRC-16644 with high productivity and NBRC-13693 with good productivity at lower $\mathrm{pH}$ area were selected. The range of optimized $\mathrm{pH}$ condition was from 5 to 7 . The $\mathrm{BC}$ would be produced from the apple pomace and the okara without the nitrogen source.

Key words: Bacterial Cellulose, Apple pomace, Okara (soy pulp), Saccharification
\end{abstract}

\section{Introduction}

A large amount of apple pomace has been discharged from apple juice processing companies in Aomori Prefecture. Recently, apple pomace has been utilized as livestock feed and soil conditioner, the amount of food processing residues for industrial waste has decreased every year. However the additional value for utilization of apple pomace has requested from these companies. Additionally, the processing industry using soybean has been working all the year round in Aomori Prefecture. The soy pulp (okara) discharged from the process to make tofu etc., and the utilization of the okara has been required too. Therefore, we are able to utilize these industrial wastes for biomass resources.

The cellulose produced by some strains of bacteria was called Bacterial Cellulose (BC), it is known to nano-fiber. The $\mathrm{BC}$ has very unique properties such as three-dimensional network, very high Young's modulus, high crystallinity, and high purity compared with plant cellulose. ${ }^{[1]}$ For example, an elastic food "nata-de-coco" was contained the $\mathrm{BC}$, and high quality loudspeakers were prepared by using the $\mathrm{BC}$. For the last few years, the $\mathrm{BC}$ has been expected to be used in new medical and industrial field. ${ }^{[2]}$ As the production costs were high, the utilization of the $\mathrm{BC}$ could not become widespread.

In this study, we investigated the conditions to produce the $\mathrm{BC}$ at low-cost, and the following five experiments were carried out; 1) screening of $\mathrm{BC}$ producer, 2) production of the $\mathrm{BC}$ by using the commercial reagents at low-cost, 3) screening of the commercial crude cellulase suitable for apple pomace, 4) production of the $\mathrm{BC}$ by using the saccharified solutions of apple pomace, and 5) production of the $\mathrm{BC}$ by using the saccharified solutions of the apple pomace and the okara.

\section{Materials and Methods \\ 2.1 Materials}

The apple pomace and the okara were provided by food processing companies in Aomori Prefecture. The discharged samples from manufacturing processes were stored at $-20^{\circ} \mathrm{C}$ before usage.

\subsection{Bacterial strains}

Strains of Gluconacetobacter xylinus NBRC-13772, NBRC-16644, NBRC-16670, NBRC-16672, NBRC-16682, and NBRC-13693 were obtained from the National Institute of Technology and Evaluation (NITE) Biological Resource Center (NBRC), and the $\mathrm{BC}-1106$ was isolated from apple-vinegar fermentation (Table I).

Table I. Strains of BC producers

\begin{tabular}{ll} 
& \multicolumn{1}{c}{ Strain } \\
\hline S-1 & NBRC-13772 \\
S-2 & NBRC-16644 \\
S-3 & NBRC-16670 \\
S-4 & NBRC-16672 \\
S-5 & NBRC-16682 \\
S-6 & NBRC-13693 \\
S-7 & BC-1106 \\
\hline
\end{tabular}

\subsection{Preculture and culture medium}

The medium was comprised of $0.5 \% \quad(w / v)$ polypepton, $0.5 \%(\mathrm{w} / \mathrm{v})$ yeast extract, $0.5 \%(\mathrm{w} / \mathrm{v})$ glucose, $0.5 \%(\mathrm{w} / \mathrm{v})$ mannitol, $0.1 \%(\mathrm{w} / \mathrm{v}) \mathrm{MgSO}_{4}$. $7 \mathrm{H}_{2} \mathrm{O}$, and $0.5 \%(\mathrm{v} / \mathrm{v})$ ethanol. This medium of No.350-medium has been recommended for an acetobacter xylinus medium by the NBRC. A preculture 
medium was the No.350-medium controlled at $\mathrm{pH} 6.8$, and a culture medium was No.350-medium controlled at $\mathrm{pH} 3,5,7,9$, and 11 .

\subsection{Purification of the BC-produced by bacteria}

The products by the fermentation were purified by 11 steps (Table II). The purified BC was white or translucent color, and elasticity of the $\mathrm{BC}$ increased with increasing the amount.

Table II. Purification of the BC from bacterial fermentation products

\begin{tabular}{|c|c|}
\hline Step & Treatment \\
\hline 1 & $\begin{array}{l}\text { Treated by } 2 \% \mathrm{SDS} \text { in a boiling water bath for } \\
2 \mathrm{hr}\end{array}$ \\
\hline 2 & Washed by distilled water \\
\hline 3 & $\begin{array}{l}\text { Treated by distilled water in a boiling water bath } \\
\text { for } 2 \mathrm{hr}\end{array}$ \\
\hline 4 & Washed by distilled water \\
\hline 5 & $\begin{array}{l}\text { Treated by } 4 \% \mathrm{NaOH} \text { in a boiling water bath for } \\
2 \mathrm{hr}\end{array}$ \\
\hline 6 & Washed by distilled water \\
\hline 7 & $\begin{array}{l}\text { Treated by distilled water in a boiling water bath } \\
\text { for } 2 \mathrm{hr}\end{array}$ \\
\hline 8 & Washed by distilled water \\
\hline 9 & $\begin{array}{l}\text { Treated by distilled water in a boiling water bath } \\
\text { for } 2 \mathrm{hr}\end{array}$ \\
\hline 10 & $\begin{array}{l}\text { Filtered by grass filter and washed by distilled } \\
\text { water }\end{array}$ \\
\hline 11 & Dried at $105^{\circ} \mathrm{C}$ until constant weight \\
\hline
\end{tabular}

\subsection{Screening of the $\mathrm{BC}$ producer}

Each of the strains was inoculated into the sterilized $20 \mathrm{ml}$ of the preculture medium with a platinum loop from slants stored at $4^{\circ} \mathrm{C}$, and cultured with shaking $(120 \mathrm{rpm})$ at $30^{\circ} \mathrm{C}$ for 3 days. After the preculture for 3 days, $100 \mu \mathrm{l}$ of the preculture medium was added to the sterilized $5 \mathrm{ml}$ culture medium in a sterilized tri-plate, and cultured statically at $30^{\circ} \mathrm{C}$ for a week. After that, the products by fermentation were purified, and weighted as the $\mathrm{BC}$.

2.6 Production of the $\mathrm{BC}$ by using the commercial reagents at low cost

The improved low cost media based on the No.350-medium were controlled at $\mathrm{pH} 5$ and autoclaved for $30 \mathrm{~min}$ at $121^{\circ} \mathrm{C}$ (Table III).

Table III. Composition of the low cost culture media for the $\mathrm{BC}$ production

\begin{tabular}{rrrrrr} 
& $\begin{array}{c}\text { Polypepton } \\
(\mathrm{w} / \mathrm{v}) \%\end{array}$ & $\begin{array}{r}\text { Yeast } \\
\text { extract } \\
(\mathrm{w} / \mathrm{v}) \%\end{array}$ & $\begin{array}{c}\text { Glucose } \\
(\mathrm{w} / \mathrm{v}) \%\end{array}$ & $\begin{array}{c}\text { Mannitol } \\
(\mathrm{w} / \mathrm{v}) \%\end{array}$ & $\begin{array}{c}\text { Ethanol } \\
(\mathrm{v} / \mathrm{v}) \%\end{array}$ \\
\hline M-1 & 0.5 & 0.5 & 0.5 & 2.0 & 0.5 \\
$\mathrm{M}-2$ & 0.5 & 0.3 & 0.5 & 2.0 & 0.5 \\
M-3 & 0.5 & 0.1 & 0.5 & 2.0 & 0.5 \\
M-4 & 0.5 & 0 & 0.5 & 2.0 & 0.5 \\
M-5 & 0.5 & 0.5 & 0.5 & 1.0 & 0.5 \\
M-6 & 0.5 & 0.5 & 0.5 & 0.5 & 0.5 \\
M-7 & 0.5 & 0.5 & 0.5 & 0.1 & 0.5 \\
M-8 & 0.5 & 0.5 & 0.5 & 0 & 0.5 \\
\hline
\end{tabular}

Each of the selected bacteria (NBRC-13693, NBRC-16644, and NBRC-16682) was cultured in 40ml of the preculture medium at $30^{\circ} \mathrm{C}$ for 3 days with shaking $(120 \mathrm{rpm})$. After the preculture for 3 days, $100 \mu \mathrm{l}$ of the preculture medium was added to the $5 \mathrm{ml}$ improved low cost media and cultured under static conditions at $30^{\circ} \mathrm{C}$ for a week. After a week, the products by fermentation were purified, and weighted as the $\mathrm{BC}$.

2.7 Screening of the commercial crude cellulase suitable for the apple pomace

The apple pomace was mixed and mashed with an equal volume of distilled water by the blender (7010S, Waring), and autoclaved for $30 \mathrm{~min}$ at $121^{\circ} \mathrm{C}$. After addition of individual enzymes of $0.1 \mathrm{~g}$ (Table IV) to a sample of $200 \mathrm{~g}$ without controlled $\mathrm{pH}$, the mixture was incubated at $40^{\circ} \mathrm{C}$ for $48 \mathrm{hrs}$ by shaking $(100 \mathrm{rpm})$, and the amount of pulp and reduced sugar in these samples were measured at $0 \mathrm{hr}, 6 \mathrm{hrs}, 24 \mathrm{hrs}$, and $48 \mathrm{hrs}$. The pulp was measured as the ratio of precipitate in a calibrated $10 \mathrm{ml}$ test tube, after centrifugation for 10 min at 3,000 rpm (H-100B, Kokusanenshinki). Reduced sugar was analyzed by Somogyi improved method for the determination of glucose. ${ }^{[3]}$

Table IV. The commercial crude cellulases for the apple pomace

\begin{tabular}{cl}
\multicolumn{2}{c}{ Enzyme name } \\
\hline E-1 & $\begin{array}{l}\text { Cellulase Y-NC } \\
\text { (Yakult Pharmaceutical Co, Japan) }\end{array}$ \\
E-2 & $\begin{array}{l}\text { Cellulase "ONOZUKA" 3S } \\
\text { (Yakult Pharmaceutical Co, Japan) }\end{array}$ \\
E-3 & $\begin{array}{l}\text { Sumizyme AC } \\
\text { (Shin-Nihon Kagaku Kogyo Co, Japan) } \\
\text { Sumizyme C } \\
\text { E-4 }\end{array}$ \\
(Shin-Nihon Kagaku Kogyo Co, Japan) \\
E-5 & $\begin{array}{c}\text { Sumizyme X } \\
\text { (Shin-Nihon Kagaku Kogyo Co, Japan) }\end{array}$ \\
E-6 & $\begin{array}{c}\text { Sumizyme ACH } \\
\text { (Shin-Nihon Kagaku Kogyo Co, Japan) }\end{array}$ \\
E-7 & $\begin{array}{c}\text { Cellulase A "Amano" 3 } \\
\text { (Amano Enzyme Co, Japan) }\end{array}$ \\
E-8 & $\begin{array}{c}\text { Cellulase A "Amano" 4 } \\
\text { (Amano Enzyme Co, Japan) }\end{array}$ \\
\hline
\end{tabular}

2.8 Production of the $\mathrm{BC}$ by using the saccharified solution of apple pomace

The apple pomace was mixed with an equal volume of distilled water by the blender (7010S Waring), and warmed in a boiling water bath for $2 \mathrm{hrs}$. The sample was mashed by the blender, and autoclaved for $30 \mathrm{~min}$ at $121^{\circ} \mathrm{C}$. After addition of $6.65 \mathrm{~g}$ of enzymes (Sumizyme AC: Shin-Nihon Kagaku Kogyo) to $2,660 \mathrm{~g}$ of the sample, the mixture was incubated under static conditions at $40^{\circ} \mathrm{C}$ for $72 \mathrm{hrs}$. The saccharified sample was boiled on a gas cooker boiling for $2 \mathrm{~min}$, and the supernatant solution of centrifugation for $15 \mathrm{~min}$ at 6,000rpm (himac CR20F, Hitachi) was filtered through a filter paper (Advantec Toyo, No. 5C). The BC production medium was prepared by the saccharified solution composed of $0.5 \%(\mathrm{w} / \mathrm{v})$ polypepton, $0.5 \%$ $(\mathrm{w} / \mathrm{v})$ yeast extract, $0.5 \%(\mathrm{w} / \mathrm{v})$ mannitol, and $0.1 \%$ $(\mathrm{w} / \mathrm{v}) \mathrm{MgSO}_{4} \cdot 7 \mathrm{H}_{2} \mathrm{O}$, and autoclaved for $30 \mathrm{~min}$ at $121^{\circ} \mathrm{C}$. After cooling, $0.5 \%(\mathrm{v} / \mathrm{v})$ of ethanol was added. This medium was divided into 6 volumes $(10 \mathrm{ml}, 20 \mathrm{ml}$, $40 \mathrm{ml}, 80 \mathrm{ml}, 120 \mathrm{ml}$, and $240 \mathrm{ml}$ ), and added to a culture vessel (a surface area was $58.8 \mathrm{~cm}^{2}$ ). The strain (NBRC-13693) was cultured in $100 \mathrm{ml}$ of the preculture medium at $30^{\circ} \mathrm{C}$ for 3 days with shaking $(90 \mathrm{rpm})$. After 3 days, $2.0 \%(\mathrm{v} / \mathrm{v})$ of the preculture medium was added individually to the $\mathrm{BC}$ production medium, and cultured under static conditions at $30^{\circ} \mathrm{C}$ for 4 weeks. After 4 weeks, the products by fermentation were purified, and weighted as the $\mathrm{BC}$. 
2.9 Saccharification of the apple pomace and the okara by the crude enzyme

The apple pomace was mixed and mashed with an equal volume of distilled water by the mixer (Kenmix KM-600, Aicohsha). The apple pomace mixed with water was represented as AW. The okara was mixed and mashed with 4 volumes of distilled water by the mixer. The okara mixed with water was represented as OW. AW and OW were mixed under the conditions of Table $\mathrm{V}$, and autoclaved for $20 \mathrm{~min}$ at $121^{\circ} \mathrm{C}$. The samples were stationary treated with $0.5 \%(\mathrm{w} / \mathrm{w})$ Sumizyme AC (Table V) for total weight of residues at $40^{\circ} \mathrm{C}$ for $24 \mathrm{hrs}$, and 4 times shaking lightly ( $3 \mathrm{hrs}, 6 \mathrm{hrs}, 9 \mathrm{hrs}$, and 12 hrs). After the enzyme treatment, the samples were autoclaved for $20 \mathrm{~min}$ at $121{ }^{\circ} \mathrm{C}$. The supernatant solution of centrifugation for $10 \mathrm{~min}$ at $9,000 \mathrm{rpm}$ (himac CR20F, Hitachi) was filtered through a filter paper (Advantec Toyo, No. 5A). The solutions were controlled at $\mathrm{pH} 5.0$ to 5.5 , and autoclaved for $20 \mathrm{~min}$ at $121^{\circ} \mathrm{C}(\mathrm{AO}-1$ to $\mathrm{AO}-6)$.

Table V. Mixture rate of AW and OW and the amount of Sumizyme AC added to sample

\begin{tabular}{lrrr} 
& $\begin{array}{c}\text { OW(g) } \\
\text { AW(g) }\end{array}$ & \multicolumn{1}{c}{$\begin{array}{c}\text { Sumizyme } \\
\text { (weight of apple pomace) }\end{array}$} \\
\hline AO-1 & $400(200)$ & 0 & 1.0 \\
AO-2 & $100(50)$ & $50(10)$ & 0.3 \\
AO-3 & $90(45)$ & $75(15)$ & 0.3 \\
AO-4 & $60(30)$ & $150(30)$ & 0.3 \\
AO-5 & $40(20)$ & $200(40)$ & 0.3 \\
AO-6 & 0 & $300(60)$ & 0.3 \\
\hline
\end{tabular}

\subsection{Production of the $\mathrm{BC}$ by using the saccharified} solutions of the apple pomace and the okara

Selected bacteria (NBRC-13693, NBRC-16682) were cultured with $20 \mathrm{ml}$ of the preculture medium for 3 days at $30^{\circ} \mathrm{C}$ by shaking (120rpm). After 3 days, $100 \mu 1$ of the preculture medium was inoculated into the AO-1 to AO-6 $(5 \mathrm{ml}$ each) in a tri-plate sterilized, and cultured under static conditions at $30^{\circ} \mathrm{C}$ for a week. After a week, the products by fermentation were purified, and weighted as the $\mathrm{BC}$.

\section{Results and Discussion}

\subsection{Screening of the $B C$ producer}

The cellulose synthesis was considered as the reaction of enzyme on the surface of cells. Enzyme reaction was influenced by $\mathrm{pH}$, therefore, it was required for the enzyme reaction efficiency to optimize $\mathrm{pH}$ for the cellulose synthesis. We investigated the production of the $\mathrm{BC}$ by 7 strains of the $\mathrm{BC}$ producer. Fig.1 shows the production of the $\mathrm{BC}$ with the each medium ( $\mathrm{pH} 3,5,7,9$, and 11). The production was different from the strains and the $\mathrm{pH}$ of the medium, particularly the production increased at $\mathrm{pH}$ from 5 to 9 . All strains could not produce the cellulose at $\mathrm{pH} 11$. The optimized condition was that $19.3 \mathrm{mg}$ was produced by NBRC-16682 with the $5 \mathrm{ml}$ of No.350 medium controlled to $\mathrm{pH} 7$. In this study, NBRC-16682 and NBRC-16644 with high productivity and NBRC-13693 with good productivity at lower $\mathrm{pH}$ area were selected. The optimized $\mathrm{pH}$ range was from 5 to 7 .

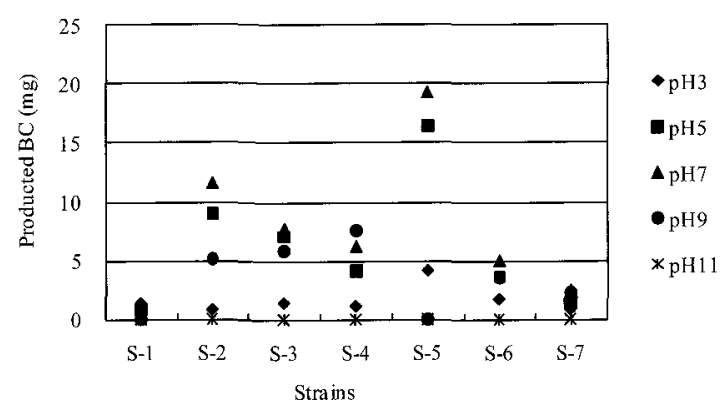

Fig.1. The production of the $\mathrm{BC}$ with the No.350 medium (pH3, 5, 7, 9, and 11) by 7 strains.

\subsection{Production of the $\mathrm{BC}$ by using the commercial reagents at low cost}

We investigated the cost efficiency of the medium with commercial reagents. In this study, the compounding rate of the Yeastextract (a high price reagent for this medium) and the Mannitol (concerned with a productivity increase of the $\mathrm{BC}$ ) were changed, and NBRC-16682, NBRC-16644, and NBRC-13693 were used for producing. The results were shown in Fig.2. The most $\mathrm{BC}$ production was $19.6 \mathrm{mg}$ of the $\mathrm{BC}$ produced by NBRC-16682 with the $5 \mathrm{ml}$ of the medium M-1, but the most efficiency of producing with the medium cost was $15.7 \mathrm{mg}$ with the medium M-4 by NBRC-16682, in this case, the $18.0 \mathrm{mg}$ of the $\mathrm{BC}$ was expected to produce with about 1 yen of the medium cost.

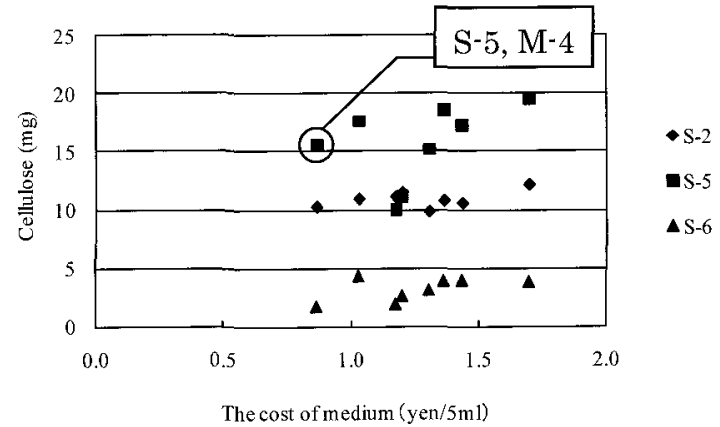

Fig.2. The relationships between the cost of improved medium and the $\mathrm{BC}$ production.

\subsection{Screening of the commercial crude cellulase suitable for the apple pomace}

For utilizing the apple pomace as the medium of the $\mathrm{BC}$ production, it was needed to treat with an enzyme. The apple pomace was individually treated with 8 kinds of commercial crude cellulases, and pulp (Fig.3) and reduced sugar (Fig.4) of saccharification samples were measured. The pulp decreased and the reduced sugar increased with time, because of the conversion of polysaccharides to mono-saccharaides in the apple pomace by the enzyme. Consequently, E-3 (Sumizyme AC) with high- efficiency was selected from these enzymes. After saccharification, the volume of the apple pomace treated with the E-3 decreased to 19.1 percent, and the apple pomace was changed from pasty to liquid state. Thus, the E-3 was assumed to be a practical enzyme. 


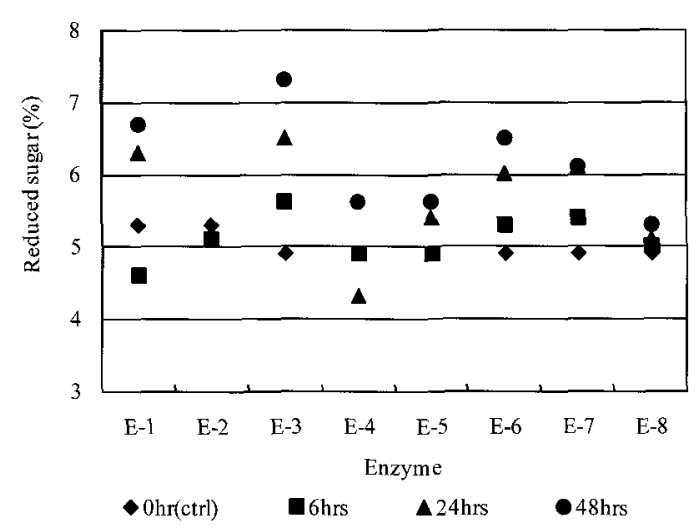

Fig.3. Pulp of saccharification samples by enzymes.

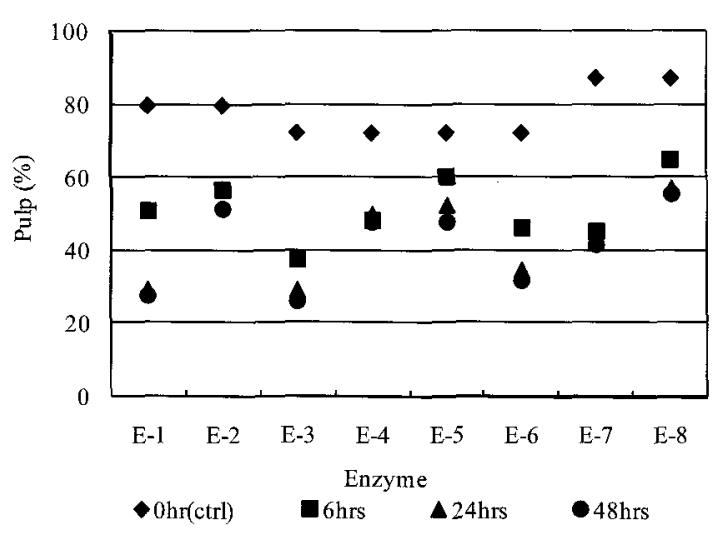

Fig.4. Reduced sugar of saccharification samples by enzymes.

\subsection{Production of the BC by using the saccharified} solution of the apple pomace

Fig.5 shows the BC produced from saccharified solution of the apple pomace. The relationship between the volume of medium, $X$, and the production of the $\mathrm{BC}$ $Y$, was $Y=2.47 X$. It was assumed that $3.3 \mathrm{~g}$ of the dry $\mathrm{BC}$ produced from $1 \mathrm{~kg}$ of the wet apple pomace, but it was needed to add the nitrogen source.

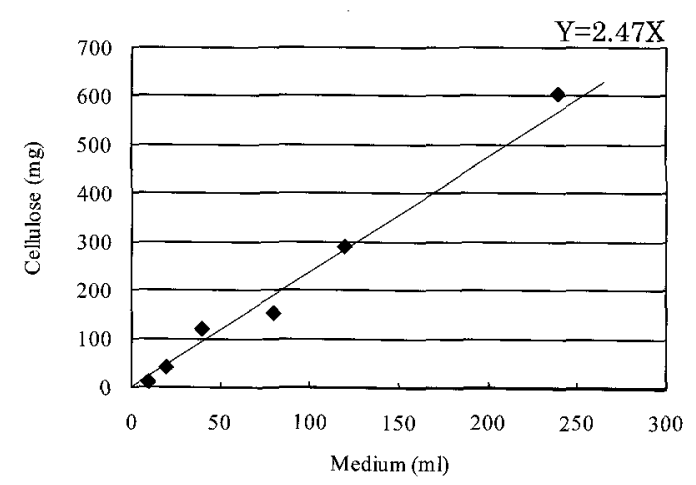

Fig.5. The BC produced from saccharified solution of the apple pomace.
3.5 Production of the $\mathrm{BC}$ by using the saccharified solutions of the apple pomace and the okara

We tried to produce the $\mathrm{BC}$ from the saccharified solutions of the apple pomace and the okara by using the NBRC-16682 and the NBRC-13693 (Fig.6). The most $\mathrm{BC}$ production was $5.1 \mathrm{mg}$ produced by the NBRC-16682 with the $5 \mathrm{ml}$ of a saccharified solution medium AO-4 (prepared from an equal amount of the apple pomace and the okara), the $5 \mathrm{ml}$ of the medium was prepared from $1.25 \mathrm{~g}$ of the apple pomace and $1.25 \mathrm{~g}$ of the okara. In the case of the NBRC -13693 , the $\mathrm{BC}$ was produced by a certain amount from 100 percent of the okara when the ratio of the apple pomace to the okara was $4: 1$, and produced slightly with the apple pomace alone. Thus it was found that the $\mathrm{BC}$ would be produced from the apple pomace and the okara without the nitrogen source.

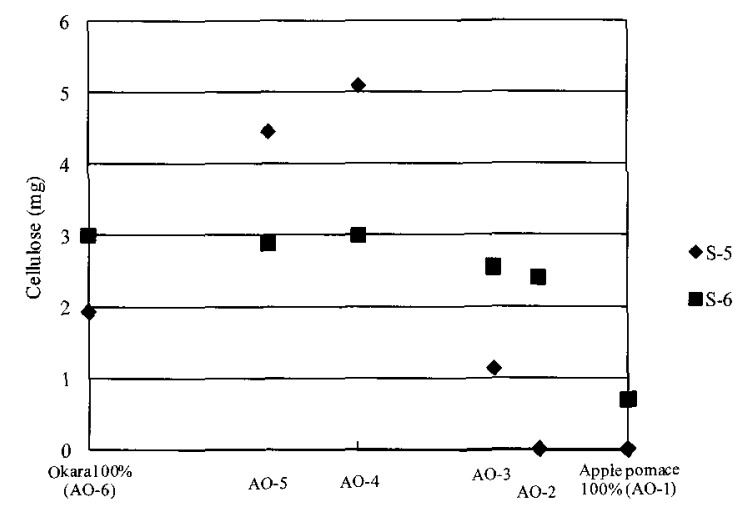

Fig.6. The $\mathrm{BC}$ produced from saccharified solutions of the apple pomace and the okara.

\section{Conclusion}

1) The strain of Gluconacetobacter xylinus NBRC-16682 was selected. 2) The $18.0 \mathrm{mg}$ of the BC was expected to produce with about 1 yen of the medium cost by using the commercial reagents. 3) Sumizyme AC was selected as the cellulase suitable for the apple pomace. After saccharification, the volume of the apple pomace treated with the enzyme decreased to 19.1 percent. 4) It was assumed that $3.3 \mathrm{~g}$ of the dry BC produced from $1 \mathrm{~kg}$ of the wet apple pomace, but it was needed to add the nitrogen source. 5) It was found that the $\mathrm{BC}$ would be produced from the apple pomace and the okara without the nitrogen source.

Furthermore, it is needed to investigate the functional compositions of the water-soluble saccharified solution or the production by the fermentation for the industrial utilization of biomass resources.

\section{References}

[1]S.Yamanaka, K.Watanabe, M.Iguchi, Y.Nishi, Nippon Nogeikagaku Kaishi., 72, 1039 (1998).

[2]M.Tabuchi, Kagaku to Seibutsu., 45, 600 (2007).

[3]T.Kobayashi, T.Tabuchi, Nippon Nogeikagaku Kaishi., 28,171 (1954).

(Recieved June 6, 2008 ; Accepted September 5, 2008) 